\title{
Determinants of Income from Agroforestry Practice in Boloso Bombe Woreda, Wolaita Zone, Ethiopia
}

\author{
Tamrat Guja Asale ${ }^{1} \quad$ Alemu Anshiso ${ }^{2}$ \\ 1.College of Business and Economics, Wolaita Sodo University, Wolaita Sodo, Ethiopia \\ 2.Business and Economics College, Wachemo University, Hossana, Ethiopia
}

\begin{abstract}
Agroforestry land use practice is important alternative land use in situations of land shortage with potential solution for the problem of declining rural agricultural productivity and land degradation. Agroforestry practice reduce the risks associated with agricultural production, increases the sustainability of agriculture and support livelihood of the farming community by generating income for smallholder farmers. Farmers are expanding the agroforestry by incorporating non-traditional fruit crops such as mango and avocado. On the other hand, some farmers are switching from agroforestry practice to expanding monocropping especially ginger production. The objective of the study was to assess determinants of income from agroforestry practice and to examine land holding and its allocation to different land uses in Boloso Bombe Woreda, Wolaita Zone, Ethiopia. The study employed household survey for primary data collection and different documents referred for secondary data. Both descriptive analysis and econometric method were employed. In econometric method multiple linear regressions was used to identify the determinants of income earned from agroforestry practice. The result reveals that average land holding of households in the study area was less than one hectare $(0.93 \mathrm{ha})$ and land size allocated for agroforestry practice is less than land allocated for monocropping system. The regression result indicates that five variables, such as, farm size, family size, access to extension service, number of livestock kept and experience of farmers are positively and significantly affect the income earned from agroforestry practice. In order to increase income earned from agriculture, general and from agroforestry practice particularly, it is important to expand extension service build their capacity in different way. Therefore, the government and other responsible bodies should give due attention to help smallholder farmers in order to use agroforestry land use for sustainability of smallholder agriculture that has been constrained by agricultural land shortages.
\end{abstract}

Keywords: Land use; income, Agroforestry practices

DOI: $10.7176 / \mathrm{JESD} / 10-9-01$

Publication date:May $31^{\text {st }} 2019$

\section{Introduction}

Ethiopian economy is highly dependent on agriculture and related activities. Consequently the agricultural sector plays an important role in the national economy and livelihood of the majority of the population. The sector supports employment over $80 \%$ of the population (Berhanu, 2006). But the sector is being characterized by low productivity due to rapid population growth, subsequent increase in human needs, lack of appropriate technologies, lack of capital for intensification technique and others (Pender, 1999). As the population continues to grow rapidly the gap between supply and demand for agricultural land continues to expand and this leads to severe land use conflicts between the crop production and forestry which causes further clearance of forest land for agricultural and other needs, which cause deforestation. Deforestation imposes environmental problems such as soil erosion, decline in the productivity of the land and increases food insecurity, which subsequently lead to socio economic problems (Kang and Akinnifesi 2000; Pech and Sunada, 2008).

Agroforestry land use is land use with this dual purpose, increases natural resources management and productivity of land (Beetz, 2002; Pech and Sunada, 2008). Agroforestry land use is very appropriate land use alternative in situations of land shortage and it is reputed as a potential solution for the problem of declining rural agricultural productivity and land degradation (Jiregna, 1998; Evan, 2011). It is land use believed to promote both productivity and environmental objectives and now receiving increasing attention as a sustainable land management option in the world because of its ecological, economic, and social attributes (SLUF, 2006). The other advantage that receives world's attention is that it can reduce the risks associated with agricultural production and it also increases the sustainability of agriculture (Martin and Sherman, 1992). Also agroforestry systems make maximum use of the land and every part of the land is considered suitable for useful plants (Motis, 2007).

Agroforestry practices have great roles to play in livelihood of the farming community because of its multiple benefits. Some of the benefits are income generation, food, fuel, construction material, fodder and shading for shade loving crops like coffee, and amenity value. These multiple benefits of the system make it more desirable than other land use and maximize the income generated from it, even if there are so many determinants that affect its income.

In the study area agroforestry land use has been a dominant practice for long time. Currently, there are two parallel developments in the agroforestry land use in the woreda. On one hand, farmers are expanding the 
agroforestry by incorporating non-traditional fruit crops such as mango and avocado. On the other hand, some farmers are switching from agroforestry practice to expanding monocropping especially, ginger production which is the major cash crop in the study area. Indeed, the agroforestry is a farming practice has been praised in the study area, recently for its ability to relax the problem due to inability to follow intensification as an option due to agricultural land shortages, and to remove the side effect due to intensification of agriculture.

The general objective was to assess determinants of income from agroforestry practice in Boloso Bombe Woreda, Wolaita Zone, Ethiopia. Specifically, the study emphasized to examine land holding and its allocation to different land uses and to identify the determinants of income from the agroforestry practices in the study area.

\section{Methodology}

\subsection{Sampling technique and Sample size}

The study area was selected purposively based on the presence of agroforestry practice potential by selecting two Kebeles (Para Ocha and Ambe Kebeles). The households were selected by following simple random sampling techniques which is the simplest form of probability sampling. The sample size, 182 households, was determined based on the rule of thumb method that is $\mathrm{N} \geq 50+8 \mathrm{~m}$, where $\mathrm{N}$ is the minimum required number of households and " $\mathrm{m}$ " is explanatory variables (Green, 1991).

\subsection{Sources and Methods of Data Collection}

In this study both primary and secondary data were used. Primary data were collected through a household survey by using a structured questionnaire, and Secondary data (the number of households and socio-economic information) were collected from different published and unpublished documents from sampled kebeles and agricultural office of Boloso Bombe Woreda.

\subsection{Methods of Data Analysis}

Descriptive statistics like mean, frequency, percentage, tables, maximum, minimum and standard deviation were used to achieve objective of examining land holding and its allocation to different land uses of selected households.

In econometrics analysis multiple linear regressions was used to identify the determinants of income from agroforestry practice in the study area. There are two variables, such as dependent and independent variables (Guajarati, 1998, Gujarati, 2004). It is a technique that allows additional factors to enter the analysis separately so that the effect of each can be estimated (Baker, 2006). It is valuable for quantifying the impact of various simultaneous influences upon a single dependent variable. Further, because of omitted variables bias with simple regression, multiple regression is often essential even when the investigator is only interested in the effects of one of the independent variables (Gujarati, 1998; Greene, 2003).

The general form of the multiple linear regression models is:-

$\mathrm{Y}=\beta_{0}+\beta_{1} \mathrm{X}_{1}+\beta_{2} \mathrm{X}_{2}+\ldots . . \beta_{\mathrm{k}} \mathrm{X}_{\mathrm{k}}+\varepsilon$

Where, $\mathrm{Y}$ is the dependent/explained variable and $\mathrm{X}_{1} \ldots \mathrm{X}_{\mathrm{k}}$ are the independent/ explanatory variables. In the case of this study "X" $\mathrm{X}_{\mathrm{I}}$.....'X' ${ }_{\mathrm{k}}$, were age, experience, education, family size, land size, access to extension service, distance from market, price of inputs, gender, number of livestock, involvement in off farm activities and ' $\mathrm{Y}$ ' is income from agroforestry and " $\varepsilon$ " is error term. The equation can be written as,

Income $=\beta_{0}+\beta_{1}$ age $+\beta_{2}$ sex $++\beta_{3} \exp +\beta_{4} \mathrm{fms}+\beta_{5}$ farm size $+\beta_{6}$ Ext $+\beta 7 \mathrm{dm}+\beta_{8}$ livestock $+\beta_{9}$ Edu $+\beta_{10} \mathrm{OFF}$ $+\beta_{11}$ price $+\varepsilon . \beta_{0}$ is intercept of the model. Regression coefficients $\beta 1, \beta 2$ and.... $\beta_{\mathrm{n}}$ are known as partial regression or partial slope coefficients. $\beta_{1}$ measures the change in the mean value of $Y, E(Y)$, per unit change in $\mathrm{X}_{1}($ age $)$, holding the value of all other explanatory variables constant and so on.

\section{Results and Discussion}

\subsection{Land holding and its allocation to different land uses}

Land is an important economic resource for the development of rural livelihoods. However, there is low supply relative to the large family size of households. As we can see from the table (Table 1), $72.4 \%$ of the respondents owned less than 0.5 hectares of land and only $27.6 \%$ of the respondents had a farm size of more than 0.5 hectares. The shortage of land is basic problem in the study area to maximize agricultural production through intensification and which is in line with the study of Getahun (2012) who revealed that the average land holding in the area was 0.43 hectare and he suggested that land shortage is a basic problem that resulted in small scale production on fragmented and degraded land. According to focused group discussion the principal reason for the low average land holding was the increase in population in the area 
Table 1 Land holding of sampled households

\begin{tabular}{ccc}
\hline land size & frequency & Percent \\
\hline Less than 0.5 hectare & 132 & 72.4 \\
Greater than 0.5 hectare & 50 & 27.6 \\
Total & 182 & 100 \\
\hline
\end{tabular}

Source: own survey results (2016)

In this study the total land was characterized with respect to the type of land use. According to the results revealed on the table 2 , the size of the land owned by the respondents varies from a minimum of 0.28 hectare to a maximum of 5.6 hectares and the total land size of the sampled households is 169.61 hectares with average landholding 0.93 hectares. Out of total landholdings, agroforestry practice covers $24.5 \%$, monocropping system covers $59.5 \%$ of total land size, and the remaining $16 \%$ covered by grazing land. It can be seen from the result the land which is covered by agroforestry was less than land covered by monocropping. Due to lack of enough land size, the grazing land left for livestock was very small. Currently the farmers prefer more land for monocropping rather than agroforestry practice. According to focused group discussion farmers are switching from the agroforestry practice to expansion of ginger production which is the most dominant cash crop in study area. This low land size will have negative impact on farming income, that the farmers can't produce extra production rather than their family consumption. This result is consistent with the study carried out by Adekunle (2009) that found that the majority of respondents $(45 \%)$ have a farm size of between 1 and 2 hectare and thirty-eight percent of respondents have a farm size of less than one hectare and this group of people can only produce what they need for their own family with little or no extra being offered for sale.

Table 2 Land allocation to different land uses

\begin{tabular}{|l|c|c|c|c|c|}
\hline & Min. & Max. & sum & Mean & Std. Deviation \\
\hline Total land & 0.28 & 5.6 & 169.61 & 0.93 & 0.80 \\
\hline Agroforestry & 0.02 & 2.5 & 41.49 & 0.23 & 0.25 \\
\hline Monocropping & 0.12 & 4.6 & 100.94 & 0.56 & 0.60 \\
\hline Grass land & 0.00 & 1.10 & 27.18 & 0.15 & 0.16 \\
\hline
\end{tabular}

Source: own survey results (2016)

\subsection{Determinants of Households Income from Agroforestry}

The multiple linear regression method was used to determine the relationships between the income of households from agroforestry practice and the explanatory variables. The regression results shows that five out of the eleven explanatory variables (the family size, farm size, farming experience, number of livestock and extension service) were statistically significant. From this variables such as family size and extension service were significant at less than $1 \%$ and positive, farm size and farming experience were significant at less than $5 \%$ and positive and number of livestock is significant at less than $10 \%$ and positive to determine the amount of income from the agroforestry practice. This implies that an increase or decrease in size of these explanatory variables will bring about an increase or decrease in the household's annual gross income at magnitudes indicated by their respective coefficients.

Table 3 Determinants of income from Agroforestry from Practices

\begin{tabular}{ccccc}
\hline Variables & Beta coefficients & Std. Error & $\mathrm{t}$ & p.value. \\
\hline AGE & 0.165 & 0.30 & 0.55 & 0.59 \\
SEX & 1.6605 & 3.69 & 0.45 & 0.65 \\
EXP & $1.0248^{* *}$ & 0.42 & 2.44 & 0.02 \\
PRICE & 3.0788 & 3.58 & 0.86 & 0.39 \\
FRM. SIZE & $8.579 * *$ & 3.73 & 2.30 & 0.02 \\
EDU & 0.3216 & 0.48 & 0.67 & 0.51 \\
F.SIZE & $5.1624 * * *$ & 1.08 & 4.78 & 0.00 \\
EXT & $3.1008 * * *$ & 0.24 & 12.92 & 0.00 \\
DFM & -0.684 & 1.52 & -0.45 & 0.65 \\
OFF & -1.8872 & 3.37 & -0.56 & 0.57 \\
TLU & $1.273 *$ & 0.67 & 1.90 & 0.06 \\
Constant & & 17.14 & -2.53 & 0.01 \\
\hline
\end{tabular}

***represents less than 1\% significance level, ** represents less than 5\% significance level, and * represents less than $10 \%$ significance level. Adjusted $\mathrm{R}^{2=} 63 \%, \mathrm{n}=182$

Family size: Family size is statistically significant at less than $1 \%$ and it is positively associated with the income from fruit-tree based agroforestry practice. This positive impact may be due to the nature of farm activity, which is labour intensive that needs more family labour. The household who have more family size is favorable to supply more family labour. This will increase income from agroforestry practice. The coefficient value indicates that, other factors held constant, when the family labour increases by one unit the income from FTBAFP will 
increase by 5.1624 ETB. This is consistent with the study of Adekunle (2009). The study conducted by kebede $e t$ al. (2013) in northern Ethiopia reveal that large family size has positive impact on farm income.

Extension service: Agricultural extension service in the study area, offers a multitude of activities such as training, visiting, arranging field days, etc. These activities have a direct impact on the attitudes and decisions of farm households. Extension service is statistically significant at less than $1 \%$ significance level and consistent with the prior expectation it is positively associated with the income from agroforestry practice. The coefficient value indicates that the farmers who have access to extension service will get by 3.1008 birr greater than farmers who have no access to extension service. As it is to be, extension services are not only important to expand the knowledge and skills of farmers to increase income, but also it is a means to deliver the message that come from research center and development agencies that enables the implementation of the technology. This is in line with study by Kebede et al. (2013) and Goitom (2009).

Farm Size: Farm size is statistically significant at less than $10 \%$ significance level found to be positively associated with income from agroforestry practice. The coefficient value of indicates that, other factors held constant, when the farm size increase by one unit the income generated from agroforestry practice will increase by 8.579 ETB. This is because of that when there is large size of land there will be more diversification of components, which increases the income from the system and which is consistent with finding of Rogers (1983), Tesfaye (2005) and Regmi (2003).

Farming experience: the result reveals that farming experience has a positive effect on income obtained from agroforestry practice at less than 5\% significance level. The coefficient value implies that, other factors held constant, when the farm experience increases by one year the income from agroforestry practice will increased by 1.0248 ETB. It is similar with the findings of Nkamleu and Manyong (2005).

Number of livestock: As the result indicated in the table, the possession of livestock (measured by Tropical Livestock Unit (TLU)) is significant at 10\% significant level and positive to determine the income from agroforestry practice. The coefficient value indicates that, other factors held constant, when the number of livestock increases by one unit the income earned from agroforestry practice will increase by 1.273 ETB with possible the logical explanation is that when there is more livestock; there will be more availability of oxen, which is the dominant source for plough farming. The finding is consistent with the finding of Muhammad (2005) and Khanal (2011).

\section{CONCLUSION AND RECOMMENDATIONS}

\subsection{Conclusion}

Agroforestry land use is very important land use alternatives in situations of land shortage and is potential solution for the problem of declining rural agricultural productivity and land degradation having the objective of promoting both productivity and environmental sustainable land management option. This study was conducted in Boloso Bombe Woreda, Wolaita Zone, Ethiopia aimed at assessing determinants of income from agroforestry practice. The total land size of the sampled households is 169.61 hectares with average landholding 0.93 hectares. Out of total landholdings of sampled households, agroforestry practice covers $24.5 \%$, monocropping system covers $59.5 \%$ of total land size, and the remaining $16 \%$ covered by grazing land. Thus land size allocated for agroforestry practice is less than land allocated for monocropping system. The results of multiple regressions identified five variables which are positively and significantly affect income earned from agroforestry practice. These variables were farm size, family size, extension service, number of livestock and farming experience. That is family size and extension service were significant at $1 \%$ and positive, farm size and farming experience were significant at $5 \%$ and positive and number of livestock is significant at $10 \%$ and positive to determine the amount of income from the agroforestry practice.

\subsection{Recommendations}

$>$ Some farmers are engaged in production of monocropping especially, ginger production due to its short maturity age. It would be better to provide improved varieties of agroforestry tree with short maturity age in order to make farmers not switch from agroforestry practice and make agroforestry practice to serve the economic and environmental development goals.

$>$ The econometric analysis result indicates that extension service is very important influencing the income from agroforestry practice. Therefore, it is important to give attention to extension service for farmers.

\section{REFERENCES}

Adekunle, V. J. 2009. Contributions of agroforestry practice in Ondo State, Nigeria, to environmental sustainability and sustainable agricultural production. Africa focus - Volume 22, Nr. 2, 2009 - pp. 27-40

Beetz, A. 2002. Agroforestry overview; Horticulture systems guide .ATTRA

Berhanu Gebremedhin, 2006. Investment in Soil Conservation in Northern Ethiopia: The Role of Land Tenure Security and Public Programs. Agricultural Economics, 29: 69-84. 
Evan, A. 2011. Resource scarcity fair shares and development; WWF-UK / Oxfam

Getahun,K.M. 2012. Economic analysis and determinants of fruit tree based agroforestry system in Wondo district, Ethiopia: comparative analysis with monocropping systems .M.Sc. thesis. Wondo Genet College of Forestry and Natural Resources, Hawassa University, Ethiopia

Goitom, A. 2009. Commercialization of smallholder farming: determinants and welfare outcomes, a crosssectional study in Enderta district, Tigrai, Ethiopia. Master Thesis. The University of Agder, Kristiansand, Norway

Green, S. 1991. How Many Subjects Does It Take To Do a Regression Analysis? Multivariate Behavioral Research Journal 26(3): 499-510

Greene. W. H. 2003. Econometric analysis $\left(5^{\text {th }}\right.$ ed). Upper Saddle River, New Jersey 07458

Gujarati, D. N. 1998. Basic Econometrics (2 $2^{\text {th }}$ ed). MacGraw Hill, Inc

Gujarati, D. N. 2004.Basic Econometrics (4 ${ }^{\text {th }}$ ed). New York, MacGraw Hill, In Hayward Group Ltd

Kang, B.T., and Akinnifesi, F.K. 2000. Agroforestry as alternative land-use production systems for the tropics, Elxvicr Science Ltd. Natural Resources Forum 24 (2000) 137- 151

Kebede, M. Dawit, G. and Luchia, T. 2013. The role of agricultural extension system on rural household income: evidence from Southesrn Tigray. Wudpecker Journal of Agricultural Research Vol. 2(8), pp. 230 - 233 , August ISSN 2315-7259

Khanal, S.2011. Contribution of agroforestry in biodiversity conservation and rural needs fulfillment.Master's Thesis to the Tribhuvan University-Institute of Forestry, Nepal

Martin, F.W. and Sherman, S. 1992. Agroforestry Principles

Motis,T. 2007. Agroforestry principles, ECHO, technical note

Muhammad, S. 2005. Socio-economic factors affecting the income of small-scale agroforestry farms in hill country areas in yemen: a comparison of OLS and WLS determinants. Small-scale Forest Economics, Management and Policy, 4(1): 117-134, 2005

Nkamleu,G. B., and Manyong,V.M. 2005. Factors affecting the adoption of agroforestry Practices by farmers in Cameroon. Small-scale Forest Economics, Management and Policy, 4(2): 135-148

Pech, S. and Sunada, K. 2008. Population Growth and Natural-Resources

Pender. J. 1999. Rural population growth, agricultural change and natural resource management in developing countries: a review of hypotheses and some evidence from Honduras; EPDT discussion paper NO.48. Washington, D.C

Regmi, N.2003. Contribution of agroforestry for rural livelihoods: A case of Dhading District, Nepal. Paper presented at The International Conference on Rural Livelihoods, Forests and Biodiversity 19-23 May 2003, Bonn, Germany

Rogers, E.M. 1983. Diffusion of innovations, Third edition, the Free Press, New York,

Sustainable Land Use Forum (SLUF), 2006. Indigenous Agroforestry Practices and their Implications on Sustainable Land Use and Natural Resources Management: The Case of Wonago Woreda. Research Report No 1. Addis Ababa, Ethiopia technologies in Uganda, Burundi, Zambia, and Malawi: a summary and synthesis

Tesfaye, A. 2005. Diversity in homegarden agroforestry systems in Southern Ethiopia. PhD. Thesis; Wageningen University, Wageningen.the adoption of agroforestry practices in Uluguru Mountains, Tanzania 